\title{
RIGA AND TALLINN IN THE LATE TSARIST ERA: MULTIETHNICITY AND SOCIAL AND POLITICAL CHANGE
}

\author{
TOIVO U. RAUN \\ Indiana University \\ E-mail: raunt@indiana.edu
}

\begin{abstract}
This article offers a comparative perspective on the impact of the rapid development of the Baltic cities of Riga and Tallinn (Ger. Reval) from the 1860s to the eve of the First World War in 1914. In many ways typical East-Central European cities, Riga and Tallinn had been dominated by a Baltic German elite for centuries until the middle of the nineteenth century. In the six-decade period until the collapse of the tsarist regime the population of the two cities mushroomed and their ethnic composition changed drastically, especially as Latvians and Estonians increasingly chose the urban option. Adapting to this growing multiethnic diversity provided a challenge for both cities in the last decades of the Russian Empire. Various forms of modernization, including industrialization, expanded trade, and new access to various options in the free professions, afforded the opportunity for upward social mobility. In the contest for hegemony between the Russian and German languages Latvian and Estonian found a niche for themselves, also buoyed by their rapidly growing numbers. Even some local political change transpired in the last years of the Russian Empire.
\end{abstract}

Keywords: Riga, Tallinn, Latvians, Estonians, Baltic Germans, Russians, modernization, multiethnicity, social change, municipal government

Strategically located on the northeastern coast of the Baltic Sea, Riga and Tallinn (Ger. Reval, Russ. Revel'), the largest cities in the Russian Baltic Provinces in the late tsarist era, constituted two of the northernmost urban complexes in a band of East-Central European municipalities that experienced similar rapid modernization and population growth in the half-century before World War I. Riga, the capital of the central Baltic province of Livland (the Kernprovinz or 'core province', as the Baltic Germans typically called it), quintupled in size between 1867 and 1913, while the population of Tallinn, the capital of the more northerly province of Estland, quadrupled in the years 1871-1913. Growing to over half a million inhabitants on the eve of World War I, Riga had become a major regional metropolis and the fifth largest city in the entire Russian Empire after St. Petersburg, Moscow, Warsaw, and Odessa. According to the census of 1913 and including 
its so-called patrimony (additional territory belonging to the city), the number of inhabitants in Riga already reached a figure of 517,264 (Krastiņš, 1978, 16-17). In contrast, with a population of 116,132 in 1913, Tallinn remained a mediumsized city, but one that nevertheless went through the same transforming socioeconomic process as Riga, only on a smaller scale (Pullat, 1966, 42).

Riga's faster and more extensive expansion was no doubt encouraged by its especially favorable location in the middle of the Baltic Provinces and closer to Western Europe than Tallinn or St. Petersburg, for that matter. However, both Riga and Tallinn stand out as part of an intriguing 'transitional border' region between east and west in northern Europe (von Hirschhausen, 1999, 475). On the one hand, they were culturally and historically Western, as seen, for example, in their traditionally Protestant or Catholic religion and centuries of rule by Germans and Scandinavians. On the other hand, by the mid-nineteenth century they had politically belonged to the East as part of the expanding Russian Empire since the Great Northern War of the early eighteenth century. This article will offer a comparison of the impact of the strikingly rapid process of modernization in these two Baltic cities in the five decades before the First World War as well as how effectively they dealt with the ongoing challenge of an expanding and increasingly diverse multiethnic population. The size aspect, i.e., the fact that the population of Riga was five times larger than that of Tallinn by 1913, will also be taken into account.

Symbolically as well as in a practical sense, the key step in initiating the onset of economic modernization in Riga and Tallinn was the decision in the early years of Alexander II's reign to dismantle their medieval fortresses and to begin the process of opening up the traditionally isolated inner cities. Expert opinion was agreed that the aged fortresses no longer had any military value. In the case of Riga the process, lasting some six years, it began in late 1857 and proved to be the more radical one, including tearing down nearly all of the city walls, transforming the former moat into an attractive city canal, and constructing broad avenues lined with extensive parks and gardens to replace the existing narrow streets (Lenz, 1954, 9-10). The second essential undertaking in stimulating economic development was the construction of the first railroad lines connecting the two cities to the emerging all-Russian network. Riga's greater economic significance was recognized already in 1861 when it was joined to the important St. PetersburgWarsaw line by a link to Daugavpils (Ger. Dünaburg, Russ. Dvinsk) in Vitebsk province. Tallinn followed nearly a decade later in 1870 as it became part of a new rail line across all of northern Estland that joined the equally strategic St. Petersburg-Moscow line (Henriksson, 1983, 66; Pullat, 1969, 16). These links began the crucial process of closely connecting the two Baltic cities with the internal Russian market, and over the next few decades the rail network continually expanded to include the smaller towns in all three Baltic Provinces (Kassebaum, 1918, 41). 
Foreign trade through Riga, which had already been important before the era of modernization, now expanded even more, also greatly aided by increasing the depth of the water and improving conditions at the city's harbor on the Daugava (Ger. Düna, Russ. Dvina) River, about 10 miles inland from the Gulf of Riga. Between the mid-1860s and 1913 Riga's share of the Russian Empire's foreign trade nearly doubled to a substantial 17.2 percent of the total, placing it just behind St. Petersburg in importance in the empire as a whole. Tallinn, although lagging far behind Riga in total foreign trade, demonstrated substantial progress as an import center, especially in the latter part of the period, as imports increased by a factor of ten in the years 1900-1913 (Corrsin, 1978, 73, 77; Lux, 2004, 97; Pullat, 1969, 27). Nevertheless, the most important economic development in these years was industrialization, especially in the last two decades before World War I. By 1913, the number of factory workers in Riga had reached 76,300 while that in Tallinn was 16,300 , which in view of the disparity in overall population actually suggests a similar level of industrial development. Interestingly, the two cities specialized in manufacturing some of the same products, e.g., railroad cars, machinery and metal works, and textiles (Corrsin, 1978, 73, 78; Pullat, 1969, 17-19). Riga's growth and industrial expansion was clearly aided by the size and wealth of its Baltic German community, who had the capital to invest in new industrial firms as well as the technical and administrative knowhow that could be applied at all levels of the production process. A key new element in providing Riga's inhabitants with access to advanced scientific and technical education was the Riga Polytechnic Institute, founded in 1862, the first such institution in the entire Russian Empire (Henriksson, 1983, 76, 90). It is noteworthy that the number of Germans in Tallinn in this period never rose above 13,000 and declined slightly in the 1880s and 1890s while their number in Riga reached a figure of nearly 79,000 in 1913 (Pullat, 1966, 42; Krastinšs, 1978, 22-23). Thus, the potential pool for a new industrial-era elite, both in managerial positions and on the factory floor, was readily at hand in Riga, but much less apparent in the case of Tallinn.

Parallel to and as a result of this transforming economic development in Riga and Tallinn came social modernization involving the massive shift from the importance of traditional social orders or categories such as nobility, clergy, or honorary citizens (estates; Ger. Stände, Russ. sosloviia) to a growing consciousness of belonging to modern social classes associated with urban life such as various levels of an emerging middle class or a rapidly expanding cohort of industrial workers. Up to the middle of the nineteenth century urban society in the Baltic Provinces remained static and largely unchanged despite the emancipation of the Estonian and Latvian serfs already in 1816-19. Freed without land, the Baltic peasants struggled economically, and their freedom of movement was heavily restricted until an important new passport law in 1863 finally permitted mobility on a large scale. It is characteristic that the leading Baltic German journalist Julius 
Eckardt, among others, referred to the years before mid-century as 'livländisches Stillleben' (Livlandic still life) (Henriksson, 1983, 1, 185). However, by the 1860s immigrants from a variety of ethnic backgrounds began streaming into the Baltic urban centers, especially Riga and Tallinn. In view of their accumulated wealth and location at the top of traditional Baltic society, it is not surprising that the Germans were best able to take advantage of the expanded options in commerce and industry. Nevertheless, the economic expansion in the last fifty years before World War I was so extensive that it afforded a wide range of new opportunities for able persons of any nationality. For example, it is noteworthy that the Latvian population of Riga markedly increased its share of employment in the following areas in the years 1881-1913: officialdom and free professions (7 to 25 percent), trade (19 to 39 percent), and handicrafts (17 to 50 percent) (von Hirschhausen, 2006, 90).

In terms of absolute numbers as well as rates of growth the Latvians in Riga and the Estonians in Tallinn showed conspicuous advancement in ownership of real estate in the two cities by the end of the period under review, as indicated by data for 1912. In the case of Riga the Latvians had become the most numerous property owners (44.7 percent), far outdistancing the Germans (31.6 percent), the Russians (10.4 percent), and the Jews (7.2 percent). Note that even though Riga was outside the Pale of Settlement, a considerable Jewish population developed there in the course of the nineteenth and early twentieth centuries. In contrast, the Jewish population in Tallinn was minimal (0.9 percent in 1913). Even among the wealthiest real estate owners, those whose property was worth 5,000 rubles or more, the Latvians had come to outnumber the Germans $(1,314$ vs. 1,286$)$ by 1912 (Pullat, 1966, 42; Krastiňš, 1978, 182-83). In Tallinn a similar process had taken place, as the number of Estonian real estate owners rose some six and a half times between 1871 and 1912, from 18.3 percent to 68.7 percent of the total. The absolute number of German and Russian property owners declined in Tallinn, probably because of a certain level of emigration among both groups and possible assimilation through intermarriage by the Russians with wealthy Estonians or Germans. Although the value of real estate in the two cities was probably not comparable in view of Riga's much larger population, it is striking that the proportion of wealthy property owners, i.e., with real estate worth 5,000 rubles or more, was much higher among the Latvians of Riga (52.7 percent) than among the Estonians of Tallinn (12.7 percent) (Pullat, 1966, 85-86, 138).

A demographic overview of the entire Russian Empire at the end of the tsarist era clearly indicates the distinctive position of the Baltic Provinces. In 1911-13 they had the lowest rate of natural increase among the fifty provinces of European Russia, and there is definite evidence that fertility began to decline earlier than elsewhere in the empire. Not surprisingly, given its location and the prevailing historical influences such as the key role of Western forms of Christianity, the Bal- 
tic region appears to have followed a demographic pattern more similar to Western rather than to Eastern Europe (Rashin, 1956, 227-29; Wetherell and Plakans, 1997, 246-47, 256-57). Nevertheless, a sufficient potential pool of immigrants certainly existed in Estland, Livland, and Kurland, and despite some mid-century reforms, continued limited opportunities for land ownership no doubt encouraged increasing movement to the cities, especially by young peasant men. Thus, the overwhelmingly dominant source for in-migrants to Riga and Tallinn was the Baltic region itself (Kruus, 1920, 21). In Riga the ethnic Latvian population mushroomed nearly sevenfold from 1867 to 1913 , from 43,980 to 187,135 or from 23.6 to 39.6 percent of the total population, while in Tallinn the Estonian increase was nearly as dramatic, growing five and a half times from 15,097 to 83,133 (51.8 to 71.6 percent of the total population) (Krastinšs, 1978, 22-23; Pullat, 1966, 42). For further detail on ethnic composition see Tables 1 and 2.

Table 1. Population of Riga by Nationality, 1867-1913 (percentages)

\begin{tabular}{rcccrcc}
\hline & Latvians & German & Russians & Jews & Others & Total \\
\hline 1867 & 23.6 & 42.9 & 25.1 & 5.1 & 3.3 & 100 \\
1881 & 32.8 & 31.0 & 19.7 & 12.2 & 4.3 & 100 \\
1897 & 41.6 & 25.5 & 16.9 & 6.5 & 9.5 & 100 \\
1913 & 41.3 & 13.5 & 19.5 & 6.6 & 19.1 & 100 \\
\hline
\end{tabular}

Source: von Hirschhausen, 1999, 482

Table 2. Population of Tallinn by Nationality, 1871-1913 (percentages)

\begin{tabular}{ccccccc}
\hline & Estonians & Germans & Russians & Jews & Others \& Unknown & Total \\
\hline 1871 & 51.8 & 34.4 & 11.3 & - & - & 100 \\
1881 & 57.4 & 27.8 & 11.1 & 2.1 & 1.6 & 100 \\
1897 & 68.7 & 17.5 & 10.2 & 1.1 & 2.5 & 100 \\
1913 & 71.6 & 10.7 & 11.4 & 0.9 & 5.4 & 100 \\
\hline
\end{tabular}

Source: Pullat, 1966, 42

The most striking aspect of the population growth in Riga and Tallinn from the 1860s to World War I was the retention and even enhancement of ethnic diversity, especially in the case of Riga. Although the Estonians constituted a clear majority of the population in Tallinn in 1913 and the Latvians held a strong plurality in Riga in the same year, in many ways the dominant demographic theme continued to be multiethnicity. In both cases the Baltic German traditional elites, despite a gradual erosion of their hegemonic position in urban society, managed to hold on 
to a considerable portion of their previous socioeconomic, political, and cultural power in this period. The ethnic Russian population, as representatives of the rapidly growing and increasingly mobile state nation of the Romanov empire, displayed its demographic vigor and made its presence felt more and more in the Baltic Provinces, especially in the last two decades before 1914. Other ethnic groups also appeared on the scene more and more, especially in the case of Riga with the influx of Jews, Poles, and Lithuanians. As the phenomenon of a Vielvölkerstadt cemented itself in Riga and Tallinn, relations among the various nationalities, who were increasingly conscious of ethnic differences, became more of an important factor in Baltic urban society. In Riga in particular no single nationality was able to dominate city life, as seen, for example, in the command of languages according to the 1913 census, which indicated that about 40 percent of the population could speak Latvian, 20 percent German, 20 percent Russian, and the remaining 20 percent something else (especially Polish and Lithuanian) (Lenz, 1954, 71, 81).

In this situation ethnic identity continued to be mutable, as it had indeed been for centuries, but now the prevailing trends were changing. Before the middle of the nineteenth century the prestigious position of the Baltic German elites and of the German language clearly fostered assimilation in that direction by any socially rising Estonians and Latvians in both town and country. However, the prevalence of the institution of serfdom and its aftereffects limited their numbers before the 1860s. Despite the preeminence of German since medieval times the great social anomaly in the Baltic region was the absence of any German-speaking peasants or lower orders in the cities. Although occasional voices had called for a planned or purposeful Germanization of the Estonian and Latvian peasantry, the majority opinion among the Baltic German elite held that this was unnecessary. As late as the second half of the nineteenth and the beginning of the twentieth century, the Baltic Germans remained convinced that Latvian and Estonian, as rustic and undeveloped tongues spoken by small-numbered, mainly peasant peoples, simply had no future. Assimilation to a large Kultursprache was viewed as inevitable (Lenz, 1956-57, 192; Berkholz, 1864, 571-73; v. d. Brüggen, 1871, 605-06; von Berent, 1907, 339-40, 342). In spite of growing recognition of Estonian and Latvian achievements during the last decades of the tsarist era (the typical adjectives describing the Baltic natives were tüchtig ('able') and fleissig ('hard-working'), the dominant Baltic German opinion was never able to move beyond a certain level of condescension in its attitudes.

In the 1860s and 1870s the position of German remained unchallenged in Tallinn and Riga and other Baltic cities, and the eager Latvian and Estonian immigrants who, for example, moved into positions as artisans or lower level officials had plenty of incentives to become Germanized as quickly as possible (Lenz, 1956-57, 194-95). Thus, it is characteristic that according to the 1881 
census 10.3 percent of ethnic Latvians in Riga had adopted German as their usual language, and in Tallinn 7.3 percent of Estonians by nationality were using German as their primary means of communication (Corrsin, 1982, 24; Jordan, 1883-1885, I, 68-69). However, a serious blow to the position of German and a major turning point in its status came in the mid-1880s with the implementation of a policy of cultural and administrative Russification in the Baltic Provinces, as the tsarist regime sought to integrate its peripheral regions more fully. The introduction of Russian as the administrative language in the institutions of local government, the courts, and the police as well as the language of instruction at all levels of education to a large extent removed the motivation for rising Estonians and Latvians to assimilate to the German cultural world (Lenz, 1956-57, 196). Although the physical Russian presence gradually increased in Riga and Tallinn, the prestige that the Russian language could claim in the Baltic region was never able to approach that formerly held by German. In this situation the Latvians and Estonians assimilated less and less to either German or Russian and even began to absorb members of other nationalities through such phenomena as intermarriage (Henriksson, 1983, 91; Lenz, 1956-57, 198-99). In addition, numerous Latvians and Estonians who had adopted German as their usual language now returned to the use of their native language in everyday life. In 1913, for example, the proportion of ethnic Latvians in Riga who were using German as their primary means of communication had dropped markedly to 2.3 percent (Wohlfart, 2004, 40).

To what extent did socioeconomic modernization lead to political change in Riga and Tallinn in this period? The tsarist regime steadfastly held on to autocratic power at the all-Russian level until forced by the Revolution of 1905 to allow a limited level of participation through the institution of the State Duma. In 1870, however, during the era of Great Reforms in the reign of Alexander II, municipal government in the mainly Russian provinces of the empire and Siberia was at least modestly modernized on the Prussian model, and this reform was also implemented in the Baltic region in 1877. Before this change urban government in Riga and Tallinn had followed a highly traditional medieval pattern in which political power remained in the hands of a tiny elite of merchants, lawyers, and artisans who simply coopted the membership from among its peers (Henriksson, 1986, 178). The new municipal government, centered in a city council that varied according to the size of the total population, was mainly elected by property and enterprise owners divided into three curiae according to the level of taxes paid. In the first elections in 1878 in Riga the new electorate increased nearly four times, but still only constituted 3.4 percent of the total population $(5,212)$ of the city. Most importantly, because of its wealth and economic power the traditional Baltic German elite totally dominated in all three curiae (Ozolina, 1976, 45-46). Nevertheless, the possibility of participating in the urban government elections for the first time helped to mobilize Latvian activists, and given the changing 
ethnic composition of Riga, they clearly felt the time had come for a real sharing of power in running the city (Wohlfart, 2006, 332; Lenz, 1954, 31). However, in 1892 under Alexander III the tsarist regime chose to move in the opposite direction by enacting a so-called counter-reform in municipal government and raising the property value qualification needed to vote, thereby reducing the electorate to less than 1 percent of Riga's total population. In this situation voter participation fell to as low as 25 percent in 1897 (Hamm, 1980, 446). In the case of Tallinn the initial impact of the reduced size of the urban electorate was similar with the Baltic Germans retaining full control until the end of the nineteenth century (Pullat, 1969, 68-69).

Despite the highly negative impact of Russification from a non-Russian viewpoint in most areas the Baltic Germans recognized that the increasingly conservative nature of the municipal government reforms meant that the tsarist regime did not intend to sweep them out of power in the Baltic cities. Indeed, relations with St. Petersburg thawed in the last two decades before 1914, as the central government came to appreciate the stability Baltic German political leadership offered in turbulent times (von Pistohlkors, 1994, 402; Henriksson, 1983, 93). Nevertheless, the Baltic Germans were powerless to stop the continuing socioeconomic and cultural advancement of the native Baltic peoples. Largely because of their Lutheran background and the emphasis placed on reading the Bible, the Estonians and Latvians were the most literate nationalities in the Russian Empire by the end of the nineteenth century with 94.1 percent of the Estonians and 85.0 percent of the Latvians over the age of ten able to read (Kappeler, 2001, 407). From their Baltic German mentors they also learned about social mobilization and self-help in the form of non-governmental organizations. For the Latvians, for example, the Riga Latvian Association, founded in 1868, played a crucial role in organizing and consolidating the activities of the city's Latvian community (Wohlfart, 2004, 52-53).

By the last years of the nineteenth century the Latvians and Estonians had begun to take over the urban governments in the smaller cities of the Baltic Provinces, and the prospect of victory in the larger cities arose. Already in 1904, an Estonian-Russian alliance was able to win election in Tallinn and followed that up with victories in 1909 and 1913, all clearly made possible by an expanding Estonian bourgeoisie. In Riga, on the other hand, despite a growing and highly mobilized electorate the Latvians were unable to wrest power from a German-Russian alliance before the end of the tsarist regime. At least some Latvians continued to vote for German-led governance in Riga, especially under the enlightened leadership of George Armitstead, mayor in the years 1901-1912, who oversaw key advances in education, public hygiene, and welfare for the poor (Pullat, 1969, 69; Hamm, 1980, 448-50; Carlberg, 1913, 166). Thus, to a certain extent the Baltic Germans in Riga succeeded in legitimizing their rule by offering good government. 
In conclusion, it may be noted that the rapid pace of social and economic modernization in Riga and Tallinn in the half-century before World War I proved to be highly comparable, but Riga's much larger size offered a broader range of opportunities for gaining wealth and upward social mobility. The contrast in size and power of attraction of the two cities also meant that Riga was ethnically more complex, thus rendering the large Latvian community's attempts to gain political power more difficult than those of the smaller Estonian one in Tallinn. The role played by the Baltic Germans, as the declining, but still powerful traditional elite, was similar in both cities, as was the attitude of the imperial government which increasingly intervened, seeking more and more control over the borderlands like the Baltic Provinces. In Riga and Tallinn in the late tsarist era the rising Estonians and Latvians found a crucial opportunity for economic advancement, upward social mobility, and a school for politics whose lessons could be applied under different circumstances. Despite the devastating upheaval and massive loss of life, World War I would provide an unexpected turning point by means of which Riga and Tallinn suddenly emerged as the capital cities of two new independent states.

\section{References}

Berent, Theodor von. 1907. Nationale Kultur (National Culture). Baltische Monatsschrift, 63 (5), 331-346.

Berkholz, Georg. 1864. Zur Nationalitätenfrage (On the Nationality Question). Baltische Monatsschrift, 9 (6), 568-575.

Brüggen, E. v. d. 1871. Unsere bäuerlichen Verhältnisse im J. 1871 (Our Peasant Relations in the Year 1871). Baltische Monatsschrift, 20 (6), 590-607.

Carlberg, Nikolai. 1913. George Armitstead als Sozialpolitiker (George Armitstead as a Social Politician). Baltische Monatsschrift, 75 (3), 161-177.

Corrsin, Stephen. 1978. Urbanization of the Baltic Peoples: Riga and Tallinn Before the First World War. East European Quarterly, 12 (1), 69-84.

Corrsin, Stephen D. 1982. The Changing Composition of the City of Riga, 1867-1913. Journal of Baltic Studies, 13 (1), 19-39.

Hamm, Michael F. 1980. Riga’s 1913 City Election: A Study in Baltic Urban Politics. Russian Review, 39 (4), 442-461.

Henriksson, Anders. 1983. The Tsar's Loyal Germans-The Riga German Community: Social Change and the Nationality Question, 1855-1905. Boulder (CO): East European Monographs.

Henriksson, Anders. 1986. Growth, Conflict, and the Limitations of Good Government, 1850-1914. In Michael F. Hamm, ed. The City in Late Imperial Russia. Bloomington (IN): Indiana University Press, 177-208.

Hirschhausen, Ulrike von. 1999. Die Wahrnehmung des Wandels: Migration, soziale Mobilität und Mentalitäten in Riga 1867-1914 (The Perception of Change: Migration, Social Mobility and Mentalities in Riga 1867-1914). Zeitschrift für Ostmitteleuropa-Forschung, 48 (4), 475-523.

Hirschhausen, Ulrike von. 2006. Die Grenzen der Gemeinsamkeit: Deutsche, Letten, Russen und Juden in Riga 1860-1914 (The Limits of Community: Germans, Latvians, Russians and Jews in Riga 1860-1914). Göttingen: Vandenhoeck \& Ruprecht. 
Jordan, Paul. 1883-1885. Ergebnisse der ehstländischen Volkszählung (The Results of the Estland Census), 3 vols. Reval: Lindfors'Erben.

Kappeler, Andreas. 2001. The Russian Empire: A Multiethnic History. Harlow: Pearson.

Kassebaum, Hermann. 1918. Kurland / Livland Estland: Eine Stätte alter, deutscher Kultur (Kurland / Livland, Estland: A Home for Old, German Culture). Berlin: Dr. Ed. Rose.

Krastiņš, Jānis ed. 1978. Rīga 1860-1917. Riga: Zinātne.

Kruus, Hans. 1920. Linn ja küla Eestis (The City and the Village in Estonia). Tartu: Noor-Eesti.

Lenz, Wilhelm. 1954. Die Entwicklung Rigas zur Grossstadt (Riga’s Development to a Metropolis). Kitzingen am Main: Holzner.

Lenz, Wilhelm. 1956-1957. Volkstumswechsel in den baltischen Ländern (Nationality Change in the Baltic Lands). Ostdeutsche Wissenschaft, 3-4 (3), 181-200.

Lux, Markus. 2004. Das Riga der Deutschen (The Riga of the Germans). In Erwin Oberländer and Kristine Wohlfart, eds. Riga: Portrait einer Vielvölkerstadt am Rande des Zarenreiches 1857-1914. Paderborn: Ferdinand Schöningh, 75-113.

Ozoliṇa, Dzidra. 1976. Rìgas 'pilsētas tēvi' un vinuu komunālā politika 1877-1913 (The 'City Fathers’ of Riga and Their Communal Policy 1877-1913). Riga: Zinātne.

Pistohlkors, Gert von, 1994. Die Ostseeprovinzen unter russischer Herrschaft (1710/1795-1914) (The Baltic Provinces Under Russian Hegemony [1710/1795-1914]). In Gert von Pistohlkors, ed. Deutsche Geschichte im Osten Europas: Baltische Länder. Berlin: Siedler, 265-450.

Pullat, Raimo. 1966. Tallinnast ja tallinlastest 1871-1917 (On Tallinn and Tallinners 1871-1917). Tallinn: Eesti Raamat.

Pullat, Raimo. 1969. Tallinna ajalugu XIX sajandi 60-ndtate aastate algusest kuni 1965. aastani (The History of Tallinn from the Beginning of the 1860s to 1965). Tallinn: Eesti Raamat.

Rashin, Adol'f Grigor'evich. 1956. Naselenie Rossii za sto let 1811-1913 gg.: Statisticheskie ocherki (The Population of Russia over a Hundred Years, 1811-1913: Statistical Essays). Moscow: Gosudarstvennoe Statisticheskoe Izdatel'estvo.

Wetherell, Charles and Plakans, Andrejs. 1997. Fertility and Culture in Eastern Europe: A Case Study of Riga, Latvia, 1867-1881 European Journal of Population, 13 (3), 243-268.

Wohlfart, Kristine. 2004. Das Riga der Letten (The Riga of the Latvians). In Oberländer and Wohlfart, Riga, 31-74.

Wohlfart, Kristine. 2006. Der Rigaer Lettenverein und die lettische Nationalbewegung von 1868 bis 1905 (The Riga Latvian Society and the Latvian National Movement from 1868 to 1905). Marburg: Herder-Institut. 